\title{
New observations of frog and lizard predation by wandering and orb-weaver spiders in Costa Rica
}

\author{
Brian Folt ${ }^{1}$ and Witold Lapinski ${ }^{2}$
}

${ }^{1}$ Department of Biological Sciences and Auburn University Museum of Natural History, 331 Funchess Hall, Auburn University, Alabama, 36849, USA. E-mail: brian.folt@gmail.com.

${ }^{2}$ Institute of Evolutionary Ecology and Conservation Genomics, University of Ulm, Albert-Einstein-Allee 11, 89069 Ulm, Germany. E-mail: wito.1@gmx.de.

\begin{abstract}
New observations of frog and lizard predation by wandering and orb-weaver spiders in Costa Rica. Studies have suggested that predation by spiders may be an important force regulating life history in neotropical frogs and lizards, but detailed descriptions of predatorprey relationships are few. Here we describe novel observations where spiders contributed to the mortality of frogs and lizards in northeastern Costa Rica, and we corrected or clarified three identification errors of spiders from the literature. The most frequently observed predators were wandering spiders (Ctenidae), which seem to be generalist predators on frogs and lizards. An orb-weaver spider (Araneidae) also contributed to frog mortality, likely after the frog became entangled in the spider's web. More detailed studies are needed to elucidate the role that spider predation contributes to frog and lizard demography in neotropical forests.
\end{abstract}

Keywords: Anura, Araneidae, Ctenidae, La Selva Biological Station, Neotropics, predators, prey, Squamata, Tirimbina Biological Reserve.

\begin{abstract}
Resumo
Novas observações de predação de anuros e lagartos por aranhas de teia e de vida livre na Costa Rica. Estudos sugeriram que a predação por aranhas pode ser uma força importante na regulação da historia de vida de anuros e largartos Neotropicais, mas descrições detalhadas das relações predador-presa são escassas. Decrevemos aqui novas observações em que aranhas contribuem para a mortalidade de anuros e lagartos no nordeste da Costa Rica e corrigimos ou esclarecemos três erros de identificação de aranhas da literatura. Os predadores mais frequentemente observados foram aranhas-andarilhas (Ctenidae), que parecem ser predadoras generalistas de anuros e lagartos. Uma aranha-de-teia-orbicular (Araneidae) também contribuiu para a mortalidade de anuros, provavelmente depois que o animal ficou preso na teia. Estudos mais detalhados são necessários para elucidar o papel que a predação por aranhas exerce sobre a demografía de anuros e lagartos em florestas Neotropicais.
\end{abstract}

Palavras-chave: Araneidae, aranhas, Ctenidae, Estación Biológica La Selva, predadores, presa, rãs, Reserva Biológica Tirimbina, Squamata.

Received 08 February 2017

Accepted 27 July 2017

Distributed December 2017 


\section{Introduction}

In the neotropical forests of Central and South America, a diverse assemblage of organisms preys on amphibians and reptiles (Greene 1988), and predation pressure has been hypothesized to affect the life histories of prey species (e.g., Andrews 1979). A relatively large body of research at La Selva Biological Station in Costa Rica has addressed the factors influencing the population and community ecology of frogs and lizards. Observations reported from La Selva and elsewhere in the Neotropics suggest the potential importance of spider predation in regulating abundances of amphibians and reptiles. In particular, the relatively large spiders of the family Ctenidae [i.e., "wandering" spiders that do not construct webs and have low site fidelity (Foelix 1992, Wise 1993)] may be one of the most frequent predators on small anurans and lizards in neotropical forests (Hayes 1983, Guyer 1988, Donnelly and Guyer 1994).

Wandering spiders are common generalist predators that occupy terrestrial, arboreal, and aquatic environments in Costa Rican rainforests. At Tirimbina Biological Reserve, a lowland site $13 \mathrm{~km}$ from La Selva, the wandering spider assemblage contains 10 species of three families (Ctenidae, Trechaleidae, Sparassidae). These spiders are large enough to prey on frogs and lizards and they partition habitat among forest, aquatic (streams, swamps), and canopy habitats (Lapinski and Tschapka 2013, Lapinski and Tschapka in press). Observations of wandering spiders in Costa Rica suggest that the spiders indiscriminately consume anurans and lizards across most taxonomic groups (Table 1); however, poisonous frogs (Dendrobatidae) are rejected upon attack (Szelistowski 1985, Murray et al. 2016).

Despite the growing body of records of herpetofaunal predation by ctenids in Costa Rica and elsewhere in the Neotropics (Menin et al. 2005, Maffei et al. 2010, 2014), the predatory spiders reported usually are either unidentified and/or poorly described. This led us to record observations of anuran and lizard predation by spiders while studying these taxa at localities in Caribbean forests of Costa Rica between 2008 and 2014 (Lapinski and Tschapka 2013, Folt 2017). Herein, we report eight new records of predator-prey interactions in which araneid and ctenid spiders consumed frogs and lizards, and we discuss relevant natural history details associated with these observations.

\section{Materials and Methods}

The primary study site was Tirimbina Biological Reserve (TBR). This private conservation reserve is located near the confluence of the Río Sarapiquí and Río Puerto Viejo $\left(10.41^{\circ} \mathrm{N}\right.$, $84.12^{\circ} \mathrm{W}$ ) in an area classified as Holdridge's Tropical Wet Forest life zone (McDade and Hartshorn 1994). We also include observations made nearby at the La Selva Biological Station (LSBS; $10.42^{\circ} \mathrm{N}, 84.02^{\circ} \mathrm{W}$ ) and from two, midelevation sites-the Rara Avis Rainforest Reserve (Rara Avis; $10.28^{\circ} \mathrm{N}, 84.05^{\circ} \mathrm{W}$ ) and the Costa Rican Amphibian Research Center's Guayacan Rainforest Reserve (CRARC; $10.05^{\circ}$ $\mathrm{N}, 83.55^{\circ} \mathrm{W}$ ).

To verify that our predation observations were novel, we reviewed the literature by querying: (1) online research databases Google Scholar and the Thomson Reuters Web of Science Core Collection (keywords: "amphibians," "reptiles," “Ctenidae," “predation," "Costa Rica"); and (2) Thomson Reuters Web of Science Zoological Record (keywords: "new record," "predation," "anura," "Costa Rica"). We then read relevant citations from these searches to determine which predator-prey interactions had been described between ctenids and and amphibians and reptiles in Costa Rica (Table 1). Identification of Central American wandering spiders can be difficult (e.g., Ctenidae), because a user-friendly taxonomic key is absent. In three reports, we noted that researchers had: (1) identified spiders only to the family level although identification to lower 
Table 1. A review of predation records of amphibians and reptiles by ctenid spiders and tarantulas at La Selva Biological Station and other comparable nearby sites in Costa Rica and Panama. "Ctenid" = unidentified member of the family Ctenidae. Sites abbreviations are LSBS (La Selva Biological Station), TBR (Tirimbina Biological Reserve), Guanacaste NP (Guanacaste National Park). ${ }^{1}$ Two predation observations of Craugastor stejnegerianus initially identified the predators as Cupiennius coccineus. However, we re-examined the photographs and verified those spiders to be Ctenus curvipes (females). ${ }^{2}$ This note did not identify the spider beyond family level; after examining the available materials, it seems most likely to be a Cupiennius sp. (juvenile), but we indicate slight uncertainty. ${ }^{3}$ This observation of a "jumping spider" predating an adult female Norops limifrons was first reported by Losos (2009); we verify the spider's identity to be the wandering spider Cupiennius getazi (female).

\begin{tabular}{|c|c|c|c|}
\hline Vertebrate species & Spider & Site & Source \\
\hline \multicolumn{4}{|l|}{ ANURA } \\
\hline \multicolumn{4}{|l|}{ Centrolenidae } \\
\hline Espadarana prosoblepon & Cupiennius sp. & Monteverde & Hayes (1983) \\
\hline \multicolumn{4}{|l|}{ Craugastoridae } \\
\hline Craugastor sp. & Cupiennius coccineus & LSBS & Szelistowski (1985) \\
\hline Craugastor bransfordii & Cupiennius coccineus & LSBS & Murray et al. (2016) \\
\hline Craugastor ranoides & Ancylometes bogotensis & Guanacaste NP & Zumbado-Ulate et al. (2009) \\
\hline Craugastor stejnegerianus & Ctenus curvipes* & Puntarenas & Ervin et al. (2007) \\
\hline Pristimantis cerasinus & Nephila clavipes & LSBS & Ganong and Folt (2015) \\
\hline Pristimantis ridens & Cupiennius sp.** & Monteverde & Jablonski (2015) \\
\hline \multicolumn{4}{|l|}{ Dendrobatidae } \\
\hline Dendrobates auratus & Sericopelma rubronitens & Taboga Island, Panama & Summers (1999) \\
\hline \multicolumn{4}{|l|}{ Hylidae } \\
\hline Agalychnis callidryas & Cupiennius coccineus & LSBS & Stynoski et al. (2014) \\
\hline Dendropsophus ebraccatus & Ctenid & LSBS & Donnelly and Guyer (1994) \\
\hline Scinax elaeochroa & Ctenid & LSBS & Donnelly and Guyer (1994) \\
\hline Smilisca sordida & Ancylometes bogotensis & Golfito & Dehling (2007) \\
\hline Tlalacohyla loquax & Ctenid & LSBS & Ugarte and Briggs (2007) \\
\hline \multicolumn{4}{|l|}{ SQUAMATA } \\
\hline \multicolumn{4}{|l|}{ Dactyloidae } \\
\hline Norops humilis & Ctenid & LSBS & Guyer (1988) \\
\hline Norops limifrons & Cupiennius getazi*** & LSBS & Losos (2009) \\
\hline
\end{tabular}

taxonomic levels was possible (Losos 2009, Jablonski 2015); or (2) identified the spiders to species, but incorrectly (Ervin et al. 2007). We emend these identifications in Table 1.

\section{Results}

Anura: Centrolenidae.-On 04 November 2011 at $2200 \mathrm{hr}$, an adult Teratohyla spinosa 
(Taylor, 1949) (Spiny Cochran Frog) was found trapped in the web of an adult female Eriophora sp. (Araneidae) by W. Lapinski at TBR. The dead frog was being consumed by the spider (Figure 1A). The spider's web was about $2 \mathrm{~m}$ above the ground near a small forest creek. We presume that the frog somehow became ensnared in the web, where it was eaten by the spider.

On 17 August 2014 at about $1930 \mathrm{hr}$, an adult male Teratohyla spinosa was attacked and killed by a subadult male Ancylometes bogotensis (Keyserling, 1877) (Ctenidae; Figure 1B). The glassfrog was calling on leafy vegetation above a small stream at La Selva and was briefly detained as part of an ongoing study of the species' population ecology (B. F., in prep.). After being measured (snout-vent length SVL $=20 \mathrm{~mm}$; mass $=0.5 \mathrm{~g}$ ), we released the frog from its site of collection; on release, the frog the frog jumped down $135 \mathrm{~cm}$ from the leaf to the soil substrate alongside the creek. The A. bogotensis was perched amidst the leaf litter adjacent to the stream; the spider quickly seized the frog in its chelicerae and retreated up a nearby stick. After watching the spider for about $2 \mathrm{~min}$, one of us (BF) collected both the spider and the frog for closer examination. The frog had been bitten in the head/left shoulder region, and quickly developed a darkened, hemorrhage-like discoloration (similar to that observed by Hayes 1983). It was dead and seemed to have died relatively quickly after being bitten. Both the spider and frog were preserved and deposited in the Auburn University Museum of Natural History (respectively: AUMS 21170; AUM 43011).

These spiders are the first known predators of Teratohyla spinosa. Ancylometes bogotensis is semi-aquatic and inhabits riparian zones alongside creeks in forested habitats (Lapinski and Tschapka 2013). The spider may be a frequent predator of $T$. spinosa in small-stream habitats where $T$. spinosa can be a dominant anuran (N. Rivera and B. Folt, in prep). Ancylometes bogotensis has been reported to prey on a number of riparian anurans throughout the spider's range in Central America and northern South America (e.g., Dehling 2007, Zumbado-Ulate et al. 2009), and it probably is a generalist predator that consumes anurans opportunistically.

Anura: Craugastoridae.-On 23 June 2011 at about $2000 \mathrm{hr}$, W. Lapinski observed an adult female Cupiennius coccineus F. O. P.-Cambridge, 1901 (Ctenidae; 1.64 g) with a Pristimantis ridens (Cope, 1866) (Rio San Juan Robber Frog; SVL $=23 \mathrm{~mm}$ ) that it had recently captured at TBR (Figure 2A). The animals were discovered $15.8 \mathrm{~m}$ above the ground during an arboreal survey for spiders. When first reported, Lapinski and Tschapka (2013) identified the frog to order; here we verify the frog's specific identity as $P$. ridens. Additionally, on 28 June 2011 at 2316 hr., W. Lapinski found a small Cupiennius sp. (13 mm body length) consuming a dead $P$. ridens (Figure 2B) near a small forest creek at TBR. The spider was found perched with its prey in a bush about $1.7 \mathrm{~m}$ above the ground. The spider was actively consuming the arms and legs of the frog.

A recent report described predation of Pristimantis ridens by a ctenid spider (Cupiennius sp.; Ctenidae) in Monteverde, Costa Rica (Jablonski 2015). We add two more observations of predation of $P$. ridens by Cupiennius spiders, and verify one of these individuals as Cupiennius coccineus. Pristimantis ridens is a common terrestrial frog usually found in the leaf litter (Ryan et al. 2015), but our observation of an individual in the mid-story/under-canopy at TBR suggests that the frog may also occur in arboreal habitats more than has been previously appreciated.

Anura: Hylidae.-On 17 September 2010, a subadult male Cupiennius coccineus was observed with a recently captured adult Duellmanohyla rufioculis (Taylor, 1952) (Rufous-eyed Stream Frog) by W. Lapinski at Rara Avis. The spider and the frog were about $1.2 \mathrm{~m}$ above the ground on the trunk of an understory palm, near a small forest creek that flows through the reserve's management facility. 

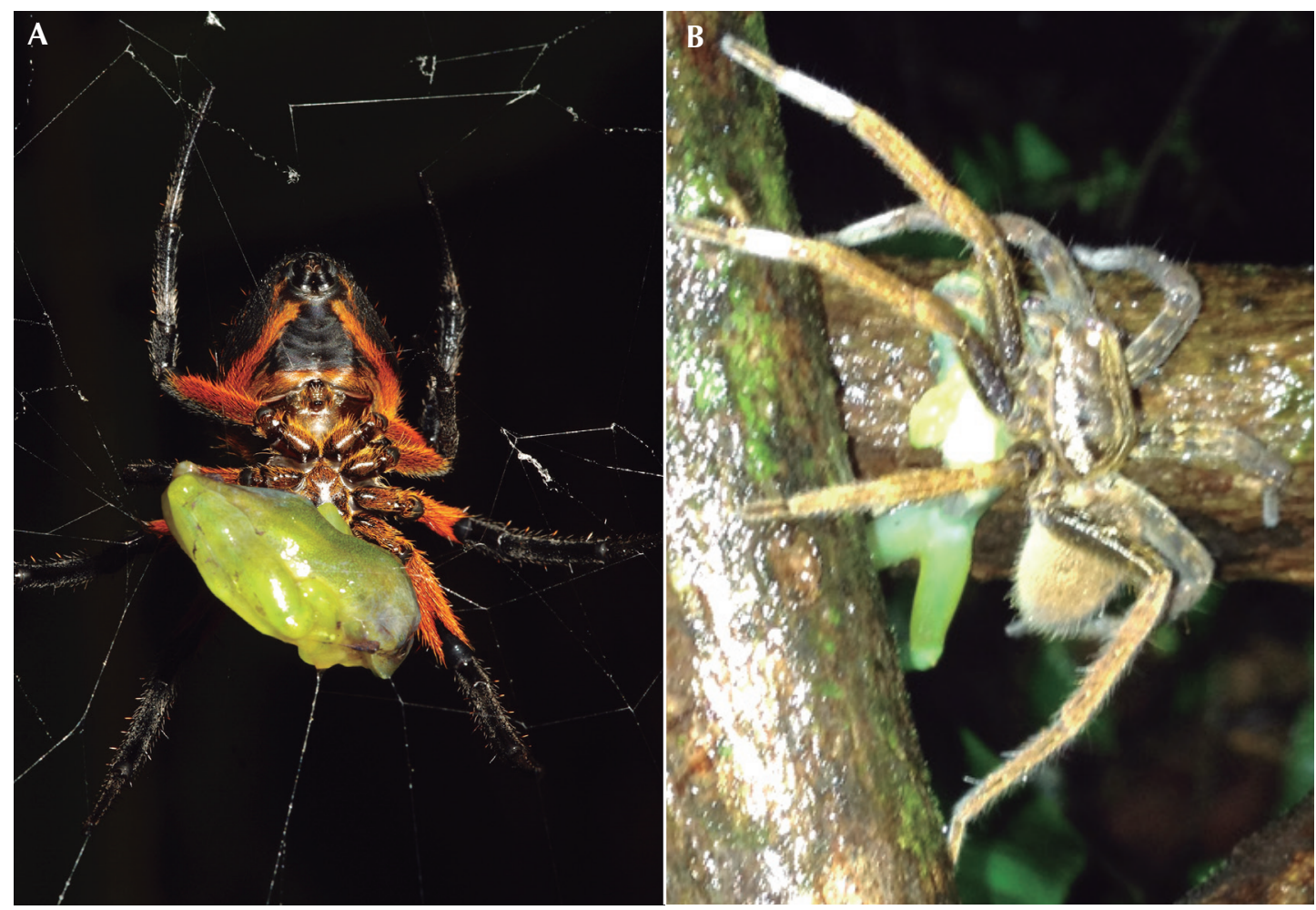

Figure 1. Predation on Teratohyla spinosa (A) by Eriophora sp. at Tirimbina Biological Reserve and (B) Ancylometes bogotensis at La Selva Biological Station, both in Costa Rica.

The animals were first observed at about $1830 \mathrm{hr}$ (Figure 3); when we returned to the location 4.5 hr later, more than one third of the frog had been consumed by the spider. To our knowledge this is the first published observation of predation on Duellmanohyla rufioculis.

Anura: Ranidae.-We observed two instances of predation on Lithobates warszewitschii (Schmidt, 1857) (Brilliant Forest Frog) by ctenid spiders. The first was 01 July 2008 at $340 \mathrm{hr}$, when a juvenile $L$. warszewitschii $(\mathrm{SVL}=26$ $\mathrm{mm}, 1.19 \mathrm{~g}$ ) was found dead in the grasp of an adult female Ctenus curvipes (Keyserling, 1881) (0.94 g; Figure 4A) along a forest trail at TBR. Initially Lapinski and Tschapka (2013) identified the frog to order; here, we verify the frog to be
L. warszewitschii. The second observation was a juvenile $L$. warszewitschii that had been recently killed by an adult female Ctenus sinuatipes F. O. P.-Cambridge, 1897 on 15 July 2011 at $2140 \mathrm{hr}$ (Figure 4B). The animals were found on a forestedge trail at the CRARC. These are the first reports of the $C$. curvipes and $C$. sinuatipes as predators on $L$. warszewitschii.

Squamata: Dactyloidae.-Predation of anoles by ctenid spiders was observed twice at TBR. On 29 June 2010 at $2000 \mathrm{hr}$, W. Lapinski observed a hatchling Norops humilis Peters, 1863 (SVL = $16 \mathrm{~mm}, 0.12 \mathrm{~g}$ ) jump into the leaf litter from a low understory plant; the anole was immediately attacked by a large juvenile female Ctenus curvipes $(0.15 \mathrm{~g})$. The spider grasped the 


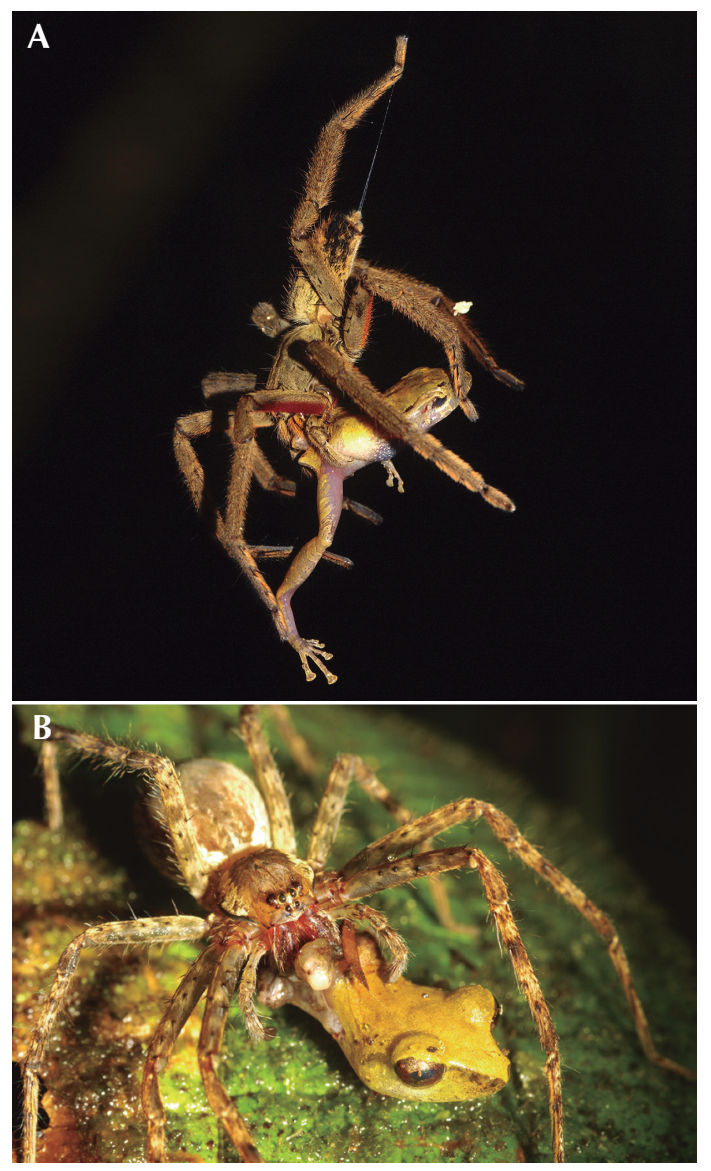

Figure 2. Predation on Pristimantis ridens by (A) an adult female Cupiennius coccineus, and (B) Cupiennius sp. at Tirimbina Biological Reserve, Costa Rica.

anole with its fangs (Figure 5A) and the anole died. Lapinski and Tschapka (2013) first identified the anole to order; here, but it is verified to be $N$. humilis. On 30 October 2011 at $1930 \mathrm{hr}$, an adult female of a small Cupiennius sp. (14 mm body length) was found with a recently captured young female Norops humilis (Figure 5B). The animals were perched on a large leaf about $1.5 \mathrm{~m}$ above the forest floor. Although predators of $N$. humilis and other anoles in Central America have been reported as

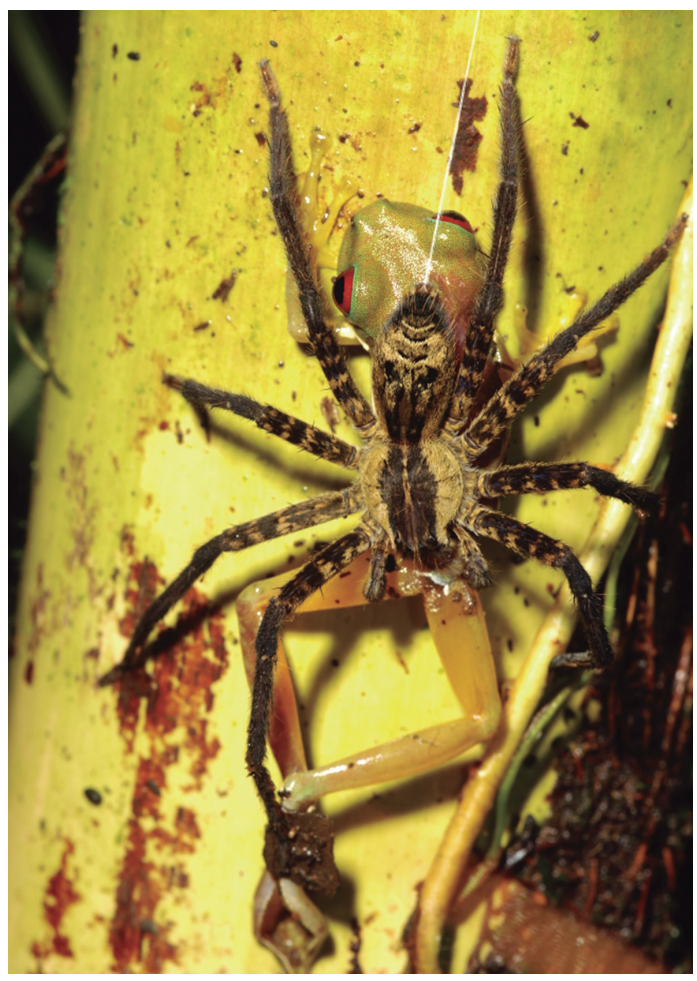

Figure 3. Predation on Duellmanohyla rufioculis by a subadult male Cupiennius coccineus at Rara Avis Rainforest Reserve, Costa Rica. After 4.5 $\mathrm{hr}$, one third of the frog had been consumed.

ctenid spiders (Guyer 1988, Losos 2009), these are the first two documented records of predation on $N$. humilis by $C$. curvipes and an unidentified Cupiennius sp.

\section{Discussion}

Ctenid spiders seem to be indiscriminant generalist predators on anurans and lizards, but they have not been observed to consume poison frogs (Dendrobatidae). Nevertheless, we did observe an adult female Ctenus sinuatipes attempt to capture an adult Oophaga pumilio (Schmidt, 1857) (Strawberry Poison Frog) at TBR (W. L.). After the spider touched the frog 

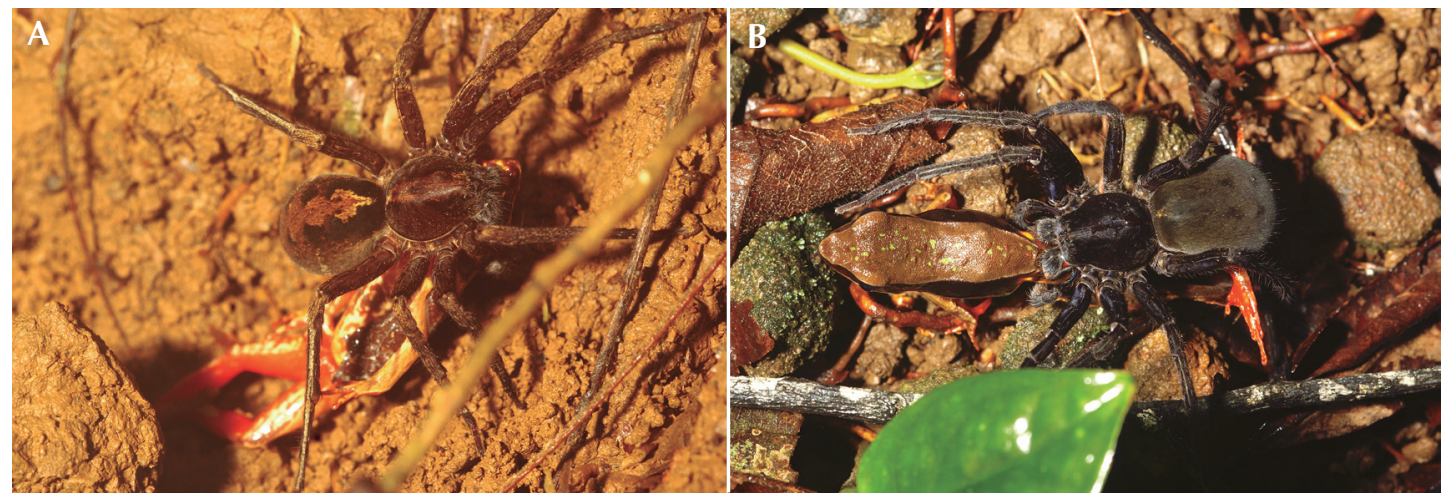

Figure 4. Predation on Lithobates warszewitschii by (A) an adult female Ctenus curvipes at Tirimbina Biological Reserve, and (B) an adult female C. sinuatipes at the Costa Rican Amphibian Research Center.

with its front legs, it immediately rejected the frog, which jumped away unharmed. This field observation is consistent with previous experiments in which $C$. coccineus attacked and then rejected O. pumilio (Szelistowski 1985, Stynoski et al. 2014, Murray et al. 2016). It is likely that the spiders evaluate dendrobatid chemical cues received during contact and deem them unpalatable (Murray et al. 2016; but see Summers 1999). Although the most frequent predators are wandering spiders of the family Ctenidae, an orb-weaver spider was observed consuming a frog caught in its web. These observations suggest that neotropical anurans and lizards are prey to a diverse assemblage of predatory spiders that may have an impact on the population ecology of their prey (Hayes 1983, Guyer 1988)—a supposition that requires more detailed study.

\section{Acknowledgments}

The National Geographic Society (Young Explorer's Grant) provided funding for BF, and the German Academic Exchange Service (DAAD) provided funding for WL. We are

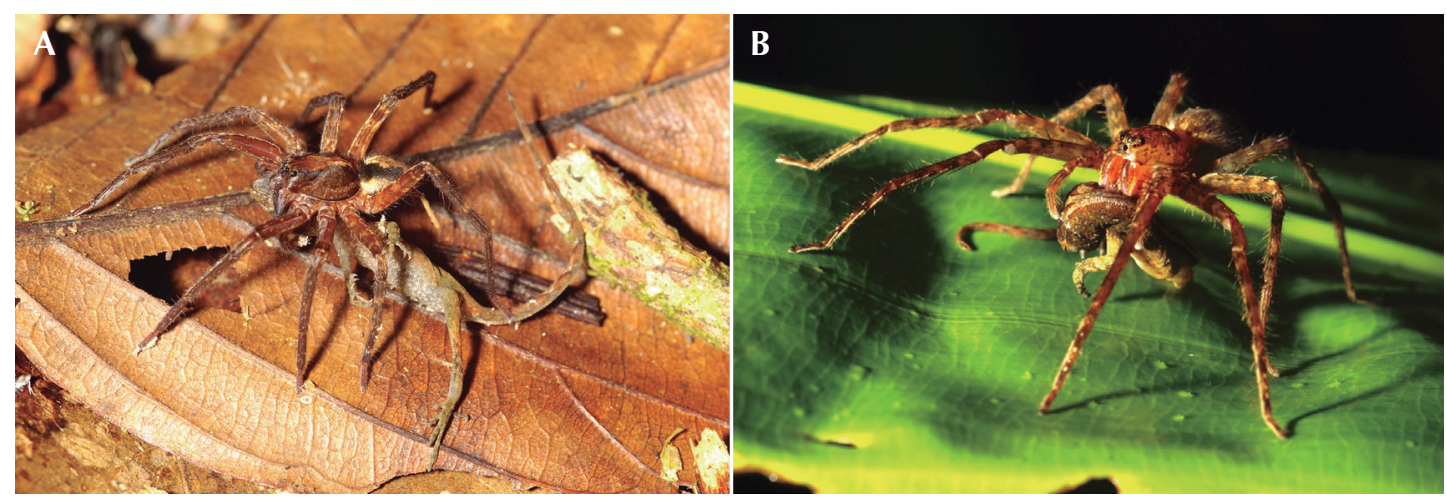

Figure 5. Predation on hatchling Norops humilis by (A) a Ctenus curvipes (female) and (B) a small Cupiennius sp. (female). 
grateful to the staff at the Reserva Biológica Tirimbina for their friendly support, and permission to complete the project at the station. The Los Angeles County Museum provided photographs for verification. We thank Ross Alford and two anonymous reviewers for providing comments on the manuscript. The research complied with permission from the Costa Rica government (MINAET) and Auburn University IACUC. We thank Javier Guevara and Lourdes Vargas (MINAET) for assistance with permitting and David Laurencio for help with the Spanish abstract. This paper is contribution no. 866 of the Auburn University Museum of Natural History.

\section{References}

Andrews, R. M. 1979. Evolution of life histories: a comparison of Anolis lizards from matched islands and mainland habitats. Breviora 454: 1-51.

Dehling, D. M. 2007. Smilisca sordida (Drab Tree Frog). Predation. Herpetological Review 38: 444.

Donnelly, M. A. and C. Guyer. 1994. Patterns of reproduction and habitat use in an assemblage of Neotropical hylid frogs. Oecologia 98: 291-302.

Ervin, E. L., R. E. Lovich, K. Gray-Lovich, N. J. Scott Jr., and J. López. 2007. Eleutherodactylus stejnegerianus (Stejneger's Robber Frog). Predation. Herpetological Review 38: 185.

Foelix, R. 1992. Biologie der Spinnen. $2^{\text {nd }}$ ed. Stuttgart. Georg Thieme Verlag. 331 pp.

Folt, B. 2017. Population regulation of frogs and lizards in a lowland wet Neotropical forest: integrating alternative hypotheses. Unpublished Ph.D. Dissertation. Auburn University, U.S.A.

Ganong, C. and B. Folt. 2015. Pristimantis cerasinus (Claycolored Rain Frog). Mortality. Herpetological Review 46: 416

Greene, H. W. 1988. Species richness in tropical predators. Pp. 259-280 in F. Almeda and C. M. Pringle (eds.), Tropical Rainforests: Diversity and Conservation. San Francisco. California Academy of Sciences and Pacific Division, American Association for the Advancement of Science.
Guyer, C. 1988. Food supplementation in a tropical mainland anole, Norops humilis: demographic effects. Ecology 69: $350-361$.

Hayes, M. P. 1983. Predation on the adults and prehatching stages of glass frogs (Centrolenidae). Biotropica 15: $74-76$.

Jablonski, D. 2015. Predation on Pristimantis ridens (Cope, 1866 ) by a wandering spider (Ctenidae Keyserling, 1877) in mountain cloud forest of Costa Rica. Herpetology Notes 8: 1-3.

Lapinski, W. and M. Tschapka. 2013. Habitat use in an assemblage of Central American wandering spiders. Journal of Arachnology 41: 151-159.

Lapinski, W. and M. Tschapka. In press. Vertical distribution of wandering spiders in Central America. Journal of Arachnology.

Losos, J. B. 2009. Lizards in an Evolutionary Tree: Ecology and Adaptive Radiation of Anoles. Berkeley. University of California Press. 528 pp.

Maffei, F., F. K. Ubaid, and J. Jim. 2010. Predation of herps by spiders (Araneae) in the Brazilian Cerrado. Herpetology Notes 3: 167-170.

Maffei, F., M. Bolfarini, and F. K. Ubaid. 2014. Predation of Scinax fuscovarius (Anura: Hylidae) by tw o invertebrates in Southeastern Brazil. Herpetology Notes 7: $371-374$.

McDade, L. A. and G. S. Hartshorn. 1994. La Selva Biological Station. Pp. 6-14 in L. A. McDade, K. S. Bawa, H. A. Hespenheide, and G. S. Hartshorn (eds.), La Selva: Ecology and Natural History of a Neotropical Rain Forest. Chicago. University of Chicago Press.

Menin, M., D. J. Rodrigues, and C. S. Azevedo. 2005. Predation on amphibians by spiders (Arachnida, Araneae) in the Neotropical region. Phyllomedusa 4: 39-47.

Murray, E. M., S. K. Bolton, T. Berg, and R. A. Saporito. 2016. Arthropod predation in a dendrobatid poison frog: does frog life stage matter? Zoology 119: 169174 .

Ryan, M. J., N. J. Scott, J. A. Cook, B. Willink, G. Chaves, F. Bolaños, A. García-Rodríguez, I. M. Latella, and S. E. Koerner. 2015. Too wet for frogs: changes in a tropical leaf litter community coincide with La Niña. Ecosphere 6: $1-10$

Stynoski, J. L., G. Shelton, and P. Stynoski. 2014. Maternally derived chemical defences are an effective deterrent against some predators of poison frog tadpoles (Oophaga pumilio). Biology Letters 10: 20140187. 
Summers, K. 1999. Dendrobates auratus (Green Poison Frog). Predation. Herpetological Review 30: 91.

Szelistowski, W. A. 1985. Unpalatability of the poison arrow frog Dendrobates pumilio to the ctenid spider Cupiennius coccineus. Biotropica 17: 345-346.

Ugarte, C. A. and V. Briggs. 2007. Hyla loquax (Swamp Tree Frog). Predation. Herpetological Review 38: 186.
Wise, D. H. 1993. Spiders in Ecological Webs. Cambridge . Cambridge University Press. 301 pp.

Zumbado-Ulate, H., F. Soley-Guardia, and F. Bolaños. 2009. Craugastor ranoides (NCN). Predation. Herpetological Review 40: 201

Editor: Ross Alford 